\title{
A HUNDRED YEARS AGO: THE ASSASSINATION OF MEHMET TALAAT (15 MARCH 1921) AND THE BERLIN CRIMINAL PROCEEDINGS AGAINST SOGHOMON TEHLIRIAN (2/3 JUNE 1921): BACKGROUND, CONTEXT, EFFECT ${ }^{1}$
}

\author{
Tessa Hofmann
}

\begin{abstract}
A hundred years ago, on the late morning of March 15, 1921, the Armenian Soghomon Tehlirian

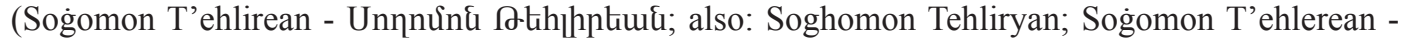
Unnnưnu Ptihjtiptiuf (1897-1960)) shot the former Ottoman Minister of the Interior (21 January 1913 to 4 February 1917), Minister of Finance (November 1914 to 4 February 1917) and head of government (Grand Vizier; 4 February 1917 to 8 October 1918), Mehmet Talaat (1874-1921) on Berlin's Hardenbergstrasse. In an unusually short time by today's standards, after two and a half months, the assassin was put on trial on 2 and 3 June of the same year at the jury court of Berlin District Court III (Landgericht Berlin III) in Berlin-Moabit. The trial lasted one and a half days, which was also unusually short. Obviously, the German or Prussian judiciary wanted to get rid of the accused and with him the subject of German-Turkish relations as quickly as possible. Tehlirian was acquitted on 3 June 1920, on the grounds of incapacity of guilt and was immediately deported from Germany. This article explains the background, context and lasting effects of his crime.
\end{abstract}

Key-words: Soghomon Tehlirian, Mehmet Tala(a)t, Armenian Genocide, Armenian Question, Operation Nemesis.

\section{Political Background: the Armenian Question}

The killing of Talaat has its origin in the genocidally answered Armenian Question. This in turn originated in Article 61 of the Berlin Treaty (1878), which contained the obligation for immediate reforms in the "provinces inhabited by Armenians" and Ottoman accountability to the six major European Powers - France, Great Britain, Austria, Russia, Germany and Italy - of the time. The Ottoman government, however, dragged out the reforms for a quarter of a century, until the then sole governing nationalist Committee for Union and Progress (Ittihat ve Terakki Cemiyeti) had no choice but to reluctantly agree in 1913 to a reform project mediated by Germany and Russia. However, it was never realized.

On 5 September 1916, Count Wolff-Metternich, the German ambassador to Constantinople, announced that the Ottoman foreign minister was on his way to Berlin to declare the international treaties "by which political shackles were imposed on Turkey as no longer binding."1 In particular, said Ambassador Metternich, Articles 61 and 62 of the Berlin Trea-

1 The article was received on 06.06.2020 and eas accepted fopr publication on 03.09.2020.

The Ambassador on an Extraordinary Mission in Constantinople (Wolff-Metternich) to the German Foreign Office; Political Archives of the Federal Foreign Office (Politisches Archiv des Auswärtigen Amtes-PA/AA), DE/PA-AA/R14093, at http://www.armenocide.net/armenocide/armgende.nsf/\$\$AllDocs/1916-09-05-DE-002, 
ty should be repealed. At that time there were almost no Armenians left in the six Armenian provinces (Vilâyat-1 Sitte) in question.

In his comprehensive testimony as an expert witness in the criminal proceedings against Tehlirian, the German theologian Dr. Johannes Lepsius (1858-1926) emphasized the direct connection between the reform plan of 1913 and the extermination of the Armenians by the Young Turkish regime in WWI:

I was in Constantinople in 1913. During the negotiations, the Young Turks were extremely upset that the Armenian reform issue was again occupying the powers and doubly bitter when, as a result of the understanding between Germany and Russia, it was settled in a manner desirable for the Armenians. At that time, the Young Turks said: "If you Armenians do not keep your hands off the reforms, something will happen, whereas the massacres of Abdul Hamid were child's play."2

\section{Punishment of Crimes against Humanity}

Reports of massacres of Armenians, which had been increasing since mid-April 1915 and the Ottoman government's actions against the "inoffensive Armenian population" in the Ottoman capital Constantinople, prompted the governments of the USA, Russia and France to issue a joint protest note on 24 May 1915. It ended with the words:

In view of those new crimes of Turkey against humanity and civilization, the Allied governments announce publicly to the Sublime-Porte that they will hold personally responsible [for] these crimes all members of the Ottoman government and those of their agents who are implicated in such massacres. ${ }^{3}$

For the first time in legal history, state and mass crimes were qualified here as a crime against humanity ${ }^{4}$ and an international tribunal was announced. But this did not materialize. After the end of the war, the Allies lacked unanimity and experience in the legal handling of such crimes.

Mustafa Arif Deymer, then Minister of the Interior and Talaat's successor in office said in his speech before the Ottoman Parliament on 21 December 1918:

Unfortunately, our wartime leaders, imbued with a spirit of brigandage, carried out the law of deportation in a manner that could surpass the proclivities of the most bloodthirsty bandits. They decided to exterminate the Armenians and they did exterminate them. This decision was taken by the Central Committee of the accessed 24.12.2019.

2 Der Völkermord an den Armeniern vor Gericht: Der Prozess Talaat Pascha. Neuaufl. Hg. und eingeleitet von Tessa Hofmann im Auftrag der Gesellschaft für bedrohte Völker. 2. ergänzte Aufl (Göttingen, Wien, 1980$), 60$. 3 Quoted from https://www.armenian-genocide.org/Affirmation.160/current_category.7/offset.50/affirmation detail.html, accessed 18.06.2019.

4 Genocidal acts are considered crimes against humanity. The term goes back to the first Geneva Convention (1864), which in turn was a reaction to the atrocities committed during the Crimean War of 1853-1855. In the Geneva Conventions and the Hague Convention on the Law of War on Land (1899), crimes against peace, war crimes and crimes against humanity are seen in close connection with each other. The preamble of the Hague Land Warfare Convention with the so-called Martens clause contains a ban on expulsion. Expulsion and deportation are classified as crimes against humanity under the Rome Statute (1998). 
Young Turks and was implemented by the Government... The atrocities committed against the Armenians reduced our country to a gigantic slaughterhouse ${ }^{5}$.

Arif established a governmental commission that examined the massacres for two months. On 18 March 1919 the oppositional daily Alemdar, basing on figures compiled by the bureau of Minister Ahmet Cemal, published as the result a figure of 800,000 Armenians who had perished between 1915 and 1917-18; these figures were repeated in the official Ottoman gazette on 21 July $1920 .^{6}$

Half-heartedly and hesitantly, the Ottoman authorities did not begin arrests until April 1919, after most of the accused or suspects had already fled abroad. In 1919 and 1920, the Constantinople court martials sentenced a total of 17 party officials to death as war criminals, although only three verdicts were executed because the remaining 14 convicts had managed to escape. ${ }^{7}$ Cemal Azmi (1868-1922) and Yenibahçeli Nail (d. 1926), both condemned to death in the Trabzon trial, managed to escape; the latter was the secretary of the Young Turkish Party responsible for the Vilayet Trabzon (Trebizond, Trapezounta) and head of the armed forces of Teşkilat-i Mahsusa, or Special Organization in this province. In the trial in Mamuret-ül-Aziz (Harput), Dr. Bahattin (Behaeddin, Bahaddin) Şakir (18741922) was sentenced to death in January 1920. In the Erzincan trial, five persons (Hafiz Abdullah Avin, Halet Efendi, Krimo Yusuf, the Kurdish tribal leader Keko, the gendarmerie sergeant Arslan) were convicted and in the Bayburt trial, Lieutenant Mehmet Necati was condemned to death.

Among the mass murderers who were sentenced to death in 1919 but escaped, were the members of the Young Turkish Triumvirate (1913-1918): Mehmet Talaat, Ismail Enver ${ }^{8}$ and Ahmet Cemal $^{9}$. Their execution and that of some of the leading executors of the genocide against the Armenians was carried out by Armenian avengers in 1920-22. But it was not only the failure of international justice or the Ottoman judiciary that drove Armenians to "hit and run" actions. The Sovietization of Armenia, and thus the loss of sovereignty, prevented Armenians from kidnapping genocide perpetrators from abroad and bringing them to justice in a sovereign state, just as Israeli intelligence officers did with Adolf Eichmann in May 1960 .

\footnotetext{
5 Vartkes S. Dolabjian, "Even Turkish sources point to 1915 genocide," The Gazette (Montreal), 11 January 1999, B2, at https://dev.anccanada.org/turkish-acknowledgments-of-the-armenian-genocide, accessed 24.12.2019.

6 Ottoman Gazette Takvimi Vekâyi no. 3909, 21 July 1920, 3-4 cited in Alemdar (Istanbul), 15 March 1919.

7 Taner Akçam, Armenien und der Völkermord: Die Istanbuler Prozesse und die türkische Nationalbewegung (Hamburg: Hamburger Edition, 1996), 157.

8 Enver was captured in Tajikistan, where he had joined pan-Islamic insurgents against the Soviets, by Hakob Melkumian's brigade. Melkumian was an Armenian from Karabakh.

9 Minister of the War Fleet 1914-1918. As commander-in-chief of the 4th Ottoman Army stationed in Syria, Djemal was directly responsible not only for the fate of the Armenians deported there, for the suppression of the uprising in the Armenian quarter of Urfa and the siege of the Armenians on Musa Dag, but also for the brutal suppression of Arab liberation movements in Syria, Lebanon and Palestine. "His order to also exterminate the 85,000 Jews of Palestine was only carried out on one third of the total because of the invasion of the British Army in November 1917. The number of Jews fell below 60,000 and about 2,500 Jewish children became orphans." Quoted from Gunnar Heinsohn, Lexikon der Völkermorde (Reinbek bei Hamburg: Rowohlt-Taschenbuch-Verl., 1998), 219.
} 
The Ottoman government's attempt to establish justice by means of national jurisdiction failed primarily because of political calculations. The Ottoman courts martial, which were held in 1919 and 1920 against members of the War Cabinet and middle-ranking government officials, were intended not only to prevent the threatened tribunal of the Allied victors, but above all to ensure the preservation of Ottoman territorial holdings - a deal that was doomed to failure. When the Allies stuck to their partition plans, armed resistance against the Allied occupation began to form from May 1919 under the leadership of the Turkish war hero Mustafa Kemal. One day after the signing of the peace treaty of Sèvres, the nationalist counter-government of Ankara abolished the courts martial to investigate the genocide crimes on 11 August 1920. After the capture of Constantinople by the nationalist, i.e. Kemalist government on 6 November 1922, the government decree of 11 August 1920 officially came into force there as well. On 31 March 1923 a general amnesty was declared, which also ensured the release of those imprisoned by the courts of war.

The three people already executed and those shot by Armenian avengers in 1921 and 1922 have since been venerated as Turkey's national martyrs. The government of the Republic of Turkey provided the relatives of the executed with generous pensions. A draft law of 29 May 1926 stipulated that the relatives of leading Turkish politicians who had been made "martyr" by Armenians "for political reasons" should receive "property from the mobile and immobile property holdings left behind by Armenians. "10

In 1921, the British Minister of War, Winston Churchill, decided to close the Allied proceedings against the suspects interned in Malta. He thus obtained the release of British hostages, whom Mustafa Kemal had threatened to shoot in the event of criminal proceedings. ${ }^{11}$

Three months after the Ottoman court martial in Constantinople on 5 July 1919 sentenced the members of the Young Turkish War Cabinet to death in absentia, the 9th Party Congress of Dashnaktsutiun (Armenian Revolutionary Federation - ARF), the party then ruling alone in the Republic of Armenia (1918-1920), dealt with the question of retaliation in the fall of 1919. There are various accounts of the outcome. According to one variant, the $9^{\text {th }}$ ARF World Congress at Yerevan passed a secret resolution called The Special Mission (Hatuk Gorts; <uunnıl qnnd) to punish those mainly responsible for the Armenian genocide: "Between 1920-1922 the perpetrators were located and felled by the Armenian avengers." 12 The Shahan Natalie Family Foundation, on the other hand, presents the establishment of Operation Nemesis [Armenian: vrej, untd] as an initiative of a minority faction within the ARF, caused by the hesitant attitude of the majority:

In view of the impotence of the Ottoman justice system, the issue of retribution against the principal organizers of the Armenian Genocide was included in the agenda of the month-long Ninth General Congress of the Armenian Revolutionary

10 At http://www.aga-online.org/worship/miscellaneous.php?locale=de, accessed 04.10.2019.

11 Akçam, Armenien und der Völkermord, 118-119. According to Rolf Hosfeld, Talaat obtained his release from his Berlin exile through the Italian Foreign Minister Sforza. Rolf Hosfeld, Operation Nemesis: Die Türkei, Deutschland und der Völkermord an den Armeniern (Köln: Kiepenheuer \& Witsch, 2005), 18.

12 Arshavir Shiragian, “Gomideh: Operation Nemesis,” at http://www.arfarshavirshiragian.org/ArmenianHistory/Nemesis/Nemesis.htm, accessed 12.12.2019. 
Federation (ARF), launched on September 27, 1919, in Yerevan. Having helped the same Young Turks come to power, the leadership of the ARF, the ruling party of the fledgling Armenian Republic, refused to take any action. Concerned by the advance of the Red Army, the ARF was, in fact, then considering aligning itself with the new Turkish authorities to stave off the Bolsheviks. As a result, the issue was tabled, to be revisited during the ARF Eleventh General Congress in 1923, after Armenia's loss of independence.

Shahan Natalie, who had vowed to punish the Genocide perpetrators upon receiving the first news of the massacres, was now concerned that failure to do so might result in more losses for the Armenian people and its newly independent republic. Angered by the party's resistance to act, Natalie led a task force with other deeply disenchanted ARF founding members, such as Grigor Merjanov [1880-?] and Armen Garo, to mete out justice to the people responsible for the Armenian Genocide. Two hundred individuals were blacklisted. Mehmed Talaat Pasha topped the blacklist. Shahan Natalie referred to him as "Number One." 13

The ARF dissidents' intent on retaliation created a secret network named after the ancient Greek goddess of revenge, which was to implement the retaliation logistically and operationally. "Our organization had no extermination plan," wrote the avenger Arshavir Shirakian in retrospect. "It inflicted punishment on individuals who had been tried in absentia and found guilty of mass murder. Armenian traitors topped our list." 14

The leadership committee of Operation Nemesis was initially headed by the former Ottoman Member of Parliament (1908-13) for Erzurum, Armen Garo (Garegin Pastermadjian - qupliqhd Фuunpúufliud (1872-1923)), who became Ambassador of the Republic of Armenia to the USA in 1919. The planning and coordination of the Special Mission was the responsibility of the revolutionary and publicist Shahan Natali (also Natalie; i.e. Hakob Ter-Hakobian; 1884-1983). ${ }^{15}$ Funding was provided by Aaron Sachaklian (1879-1964), the "financial wizard" of Nemesis: "... It can be said that Garo was the soul, Natalie the heart, and Sachaklian the head of Operation Nemesis. " ${ }^{16}$ At the end of 1922, when the ARF had to move its headquarters to Bucharest after the Kemalists took the Ottoman capital, Operation Nemesis apparently ended. ${ }^{17}$ Shahan Natali was removed from his leadership position at the $11^{\text {th }}$ World Congress of the ARF in 1929. ${ }^{18}$

Tehlirian's assassination of Talaat, the "Number One," was followed on 18 July 1921 in Constantinople by the assassination of Behbud (also: Bihbud, Pipit) Jivanshir Khan, the leader of the Musavat Party and Minister of the Interior of Azerbaijan, when up to 30,000 Armenians were slaughtered in September 1918 after Baku was captured by Turkish troops. Misak Torlakian (1889/90-1968), Jivanshir's executioner, was arrested and beaten up by

13 Memoirs of a Stranger, at https://snff.org/bookstore/memoirs-stranger/, accessed 14.05.2019.

14 Jacques Derogy, Resistance and Revenge: Armenian Assassination of Turkish Leaders Responsible for the 1915 Massacres and Deportations (London, New York: Routledge, 2016), XXVII.

15 Shahan Natalie, A Biography, at https://snff.org/about/shahan-natalie/, accessed 24.12.2019.

16 Marian Mesrobian MacCurdy, Sacred Justice: The Voices and Legacy of the Armenian Operation Nemesis (New Brunswick, London: Transaction Publishers, 2015), 45, 122.

17 Ibid., 128.

18 Ibid. 
French security forces, but was later handed over to the British occupying forces, whose court acquitted him in November $1921,{ }^{19}$ as in the case of Tehlirian before, because of Torlakian's disability of guilt.

Shortly afterwards, on 5 December 1921, the former Ottoman Grand Vizier (head of government) Sait (Said) Halim was shot dead in Rome by the young Arshavir Shirakian (1902-1973). Together with Aram Yerkanian (Yerganian; 1890-1934), Shirakian subsequently shot Cemal Azmi, the "Butcher of Trebizond," and Bahattin Şakir, who as a member of the C.U.P.'s Central Committee and a leading member of the Special organization was responsible for the extermination of Armenians in the Eastern provinces in Berlin-Charlottenburg on 17 April 1922. The group's plan was actually to eliminate the entire Ittihad leadership, which at the time had found shelter in Berlin. To this end, Hra(t)ch Papazian, disguised as a wealthy Turkish student, had already infiltrated Turkish circles in Berlin and informed his companions Natali and Shirakian daily. ${ }^{20}$

On 25 July 1922, Ahmet Djemal was gunned down in the Georgian capital Tbilisi directly in front of the headquarters of the Soviet intelligence service Cheka by the Armenian avengers Petros Ter-Poghosian, Artashes Gevorkian, and Stepan Tsaghikian.

\section{Mehmet Talaat: A Genocide Perpetrator}

Talaat, like many leaders of the Young Turkish Union and Progress Party, originated from the Balkans, ${ }^{21}$ more precisely from the small town of Karcali (today Bulgaria) in the former Thracian province of Alexandroupolis (Turkish: Edirne).

Here the coexistence of the ethno-religious communities had already become precarious in the late 19th century. Edirne itself was temporarily lost to Ottoman rule in the Russian-Turkish wars of 1828-1829 and 1877-1878 and during the Balkan wars of 1912-1913. In 1877, the family temporarily fled Edirne with Talaat, who was barely three years old, from the Russian army. ${ }^{22}$

At 18, Talaat lost his father, who had been a low-ranking civil servant. Without a high school diploma, Talaat was taken into the civil service and began a career as a telegraph official. He earned an additional income as a Turkish teacher at the modern school of the Alliance Israélite Universelle in Edirne. The principal's daughter gave him French lessons. "This seems to be the only background for the speculation that Talaat was a dönme, i.e. a Jew converted to Islam. "23

19 Vartkes Yeghiayan, Ara Arabyan, The Case of Misak Torlakian (Glendale, CA: Center for Armenian Remembrance, 2006).

20 "The Punishment of those responsible for the Armenian Genocide," at https://www.hayastan.com/armenia/ genocide/punishment/index.html, accessed 05.05.2019.

21 Erik Jan Zürcher, “The Young Turks - Children of the Borderlands?" at https://www.academia.edu/847449/ The_Young_Turks_Children_of_the_Borderlands, accessed 11.05.2019.

22 Hans-Lukas Kieser, Mehmet Talaat - eine Identifikationsfigur? Eine biografische Skizze; leicht gekürztes Manuskript eines Vortrags im Rahmen der Veranstaltung "Schwierigkeiten des Erinnerns - Der Völkermord an den Armeniern," slightly abridged manuscript of a lecture given at the event "Difficulties of Memory - The Armenian Genocide" in Berlin, University of the Arts, 18 March 2006, 2. Kieser is also the author of the first biography of Talaat; cf. Hans-Lukas Kieser, Talaat Pasha: Father of Modern Turkey, Architect of Genocide, trans. by Tessa Hofmann (Princeton, NJ; Oxford: Princeton University Press, 2018).

23 Kieser, Mehmet Talaat, 2. 
Although of Pomak ${ }^{24}$ origin, Talaat, in his memoirs ${ }^{25}$ written in Berlin in 1919/20, i.e., shortly before his death, "made an almost embarrassingly touching effort to prove his descent only from 'old and genuine' Turks - testimony to a zeitgeist that made mischief with ethnic descent, namely human appreciation and devaluation. "26

In 1895 Talaat was arrested for opposition against the Sultan, pardoned in 1897 and assigned to the postal service in Selanik (Thessaloniki), in what is now northern Greece. The cosmopolitan garrison city became the center of the Young Turks' movement, because it was possible to bring together civil and military opponents who believed in Western progress and to create an organizational unification with the Young Turks in European exile. Talaat's position in the Union and Progress Party was excellent when the party partially seized power in July 1908 through an army insurrection, had the Ottoman constitution restored and deposed the autocratic Sultan Abdül-Hamid in 1909. Talaat was elected to the Ottoman Parliament as a representative for Edirne and became Minister of the Interior in 1909, at the age of 35 .

In the turbulent period from 1911 to early 1913, when Italy invaded Libya and the united Balkan states attacked the Ottoman Empire, Talaat temporarily lost his post. However, after his party's coup in January 1913 against the government of liberal forces that had just been installed, he became more influential than ever. In early 1913, the dictatorial one-party rule of the Young Turks, which lasted until October 1918, began. Talaat was again Minister of the Interior and from February 1917 he was head of government with the title Pasha.

During the war years Talaat was the main responsible for the deportation of the Armenian population almost throughout the Ottoman Empire and for the deportations and expulsions of the Greek Orthodox population in the Pontus area ${ }^{27}$ and Western Anatolia during the First World War. According to a survey-based projection by the German Embassy in Constantinople on 4 October 1916, one and a half of 2.5 million Armenian citizens of the Ottoman Empire died of hunger, exhaustion and epidemics, in massacres or on death marches. ${ }^{28}$ These crimes, planned and directed by the state, were already judged as annihilation by contemporary German observers, including the Imperial German Ambassador himself. ${ }^{29}$

24 The ethnic affiliation of the Pomaks is disputed between Bulgaria and Greece; for Bulgaria the Pomaks are Slavs, for the Greeks, Thracians. Their membership in the Indo-European language family is undisputed. Pomaks are Bulgarian-speaking Muslims.

25 Hülya Adak, "Identifying the 'Internal Tumors' of World War I: Talat Paşa'nın Hatıraları; or, the Travels of a Unionist Apologia into History," in Räume des Selbst: Selbstzeugnisforschung, ed. by Andreas Bähr, Peter Burschel, Gabriele Jancke (Köln, Weimar, Wien: Böhlau, 2007), 151-172.

26 Kieser, Mehmet Talaat, 2.

27 84,000 was the average number used by Rudolph Rummel, and 91,000 Greek victims was the highest figure. Greek authors assume a total of 353,000 Greek victims in the Pontus area alone in 1916-1922. Cf. Rudolph Rummel, Statistics of Democide: Genocide and Mass Murder since 1900 (Münster: LIT, 1998), 96.

28 Letter from Ambassador Radowitz to the Chancellor Bethmann Hollweg; Political Archives of the German Foreign Office, PA/AA, R14093, at

http://www.armenocide.net/armenocide/armgende.nsf/\$\$AllDocs/1916-10-04-DE-002, accessed 02.09.2019. 29 Report by Ambassador Wangenheim to Chancellor Bethmann Hollweg, 7 July 1915: "The expulsion and relocation of the Armenian people was limited until 14 days ago to the provinces nearest to the eastern theatre of war and to certain areas in the province of Adana; since then the Porte has resolved to extend these measures also to the provinces of Trebizond, Mamuret-ul-Aziz and Sivas and has begun with these measures even though these parts of the country are not threatened by any enemy invasion for the time being. This situation and the way in 
Moreover, as his own records show, Talaat was an accurate accountant of the extermination:

Throughout 1915-16, Talaat, the Ottoman Minister of Interior, supervised the destruction of Armenians in the Ottoman Empire. Masking this process as a security measure, he ordered the general deportation of Armenians and oversaw the breakup of communities, the systematic confiscation of property, forced conversions, the disappearance of hundreds of thousands of people, and the dispersion of survivors across the empire. Talaat received progress reports from different provinces and, at the end of 1916, ordered a general assessment of his work. On 24 August 1916, he sent a cipher telegram to 34 provinces (vilayets and mutasarrifliks) asking for detailed information about the presence of Armenians in different parts of the empire. (...) According to Talaat's adjusted figures, around 1,150,000 Ottoman Armenians (or 77 percent) had disappeared between 1914 and $1917 .{ }^{30}$

With his appointment as head of government on 4 February 1917, Talaat was at the height of his career:

Two months earlier, he had made an inspection tour of the Anatolian provinces and, in a telegram to the sherif, the religious dignitary, from Mecca, he had proudly stated that Armenian houses and businesses had passed into Muslim hands. In this telegram, one hears the voice of a social technologist, but also the voice of a Balkan Turkic champion who sees himself collectively as a victim and who believes that he has finally gained a territorial foothold in Anatolia and this time has triumphed successfully over Christians.

As late as spring 1918 (...) (Talaat) received congratulatory telegrams for his 'services to Turkishness.' (...) Talaat's decline was all the more rapid in the second half of the year, when Bulgaria withdrew from the war alliance and Germany's defeat became clear. On October 8, 1918, he resigned as grand vizier. On November 1, just a few hours before he fled to Germany, he admitted his political defeat in a farewell speech at the last party congress sought to mitigate his complicity in the war and justified his failure to fight against abusers and war profiteers by saying that unity was a priority in the world war. ${ }^{31}$

With German help, Talaat, together with other high-ranking leaders of the Young Turkish Committee, had left the country shortly before the Ottoman war capitulation (Mudros, 30 October 1918) and escaped Ottoman or Allied jurisdiction. On 2 November 1918, he was transferred from the Ukrainian seaport of Sevastopol, together with other high-ranking Young Turks - the former ministers Enver and Cemal and the Young Turkish Party secretary Dr. Nazim (1872-1926). Talaat was evacuated by a German torpedo boat and arrived in Berlin in December 1918, where he moved into a nine-room apartment in Berlin-Char-

which the relocation is being carried out shows that the government is indeed pursuing its purpose of eradicating the Armenian race from the Turkish Empire." PA/AA, R14086, at http:/www.armenocide.net/armenocide/ armgende.nsf/\$\$AllDocs/1915-07-07-DE-001, accessed 26.11.2019.

30 Ara Sarafian, Talaat Pasha's Report on the Armenian Genocide, 1917 (London: Gomidas Institute, 2011$), 5$. 31 Kieser, Mehmet Talaat, 6. 
lottenburg under the alias Aly Saly Bey (Mehmet Sait Bey) at Hardenbergstrasse 4 with his wife Hayriye and initially, Dr. Nazım as well. As early as 1918 and 1919, respectively, the Ottoman government requested the German government to extradite Talaat, but the German Foreign Minister Wilhelm Solf rejected both requests with, among other reasons: "Talaat has been loyal to us, and our country remains open to him." 32 In absentia, Talaat was sentenced to death on 5 July 1919 by an Ottoman court martial in Constantinople for war crimes and the "massacre and annihilation of the Armenian population of the Empire." However, the victorious Turkish nationalists under the leadership of Mustafa Kemal immediately overturned the verdicts of the Ottoman court martials after they had come to power in full. ${ }^{33}$

Until his death, Talaat understood the annihilation of the Armenians in the Ottoman Empire, for which he was mainly responsible, as a necessary evil to save Turkey. The US ambassador Henry Morgenthau quoted Talaat in 1918 with the admission:

It is no use for you to argue, Talaat answered, we have already disposed of three quarters of the Armenians; there are none at all left in Bitlis, Van, and Erzerum. The hatred between the Turks and the Armenians is now so intense that we have got to finish with them. If we don't, they will plan their revenge. ${ }^{34}$

The German Foreign Office therefore assumed that Talaat was particularly endangered by Armenian avengers in Berlin and proposed a remote Mecklenburg estate as his residence. Talaat declined because it was easier for him to maintain his intense international political contacts from Berlin. ${ }^{35}$ The Young Turkish leaders who had fled abroad sought

to promote the Turkish national struggle in the European metropolises (...) with propaganda, relationship work and as organizers of the Turkish elite diaspora. They were planning an early return home and renewed participation in power. For this reason, they corresponded with Mustafa Kemal, who was the head of the Anatolian resistance from the spring of 1919. Entirely in keeping with the ideological conglomerate of the party during the World War, Talaat proposed, in a letter to Kemal, that the struggle be led primarily to victory in the homeland of Anatolia, but also that the card of Pan-Turkish and pan-Islamic solidarity be played. He also asked him for money, by the way. In his reply, in which he addressed him in good party tradition as "my brother," Kemal himself complained about lack of money. All the more important then was Soviet support for Turkish nationalism.

It is remarkable how Talaat made Soviet Russian, German nationalist and pro-fascist Italian contacts. What united him with some socialists, despite his Turkishness, was his hatred of tsarist Russia and a revolutionary self-image. ${ }^{36}$

32 Vahakn N. Dadrian, German Responsibility in the Armenian Genocide: A Review of the Historical Evidence of German Complicity (Cambridge: MA., 1996), 217.

33 Akçam, Armenien und der Völkermord, 114-119.

34 Henry Morgenthau, Ambassador Morgenthau's Story. Eighth Article [The World's Work, December 1918], at http://jfredmacdonald.com/worldwarone1914-1918/armenian-18ambassador-morgenthau-8th.html, accessed 05.06.2020.

35 Hosfeld, Operation Nemesis, 13.

36 Kieser, Mehmet Talaat, 7. 
In the judgment of European and North American contemporaries Talaat is described as a power-hungry, dictatorial, energetic, unscrupulous and irreligious person. In a dispatch to Chancellor Theobald von Bethmann Hollweg, the German extraordinary ambassador Wolff-Metternich described Talaat as the cold-blooded "soul of the Armenian persecutions." "37 Talaat was convinced that his deportation orders were justified from the standpoint of national Turkish-Muslim interests. The Turkish nationalist and feminist Halide Edip Ad1var (1884-1964) quoted Talaat on the "Armenian Question" in her event-close published memoirs:

Look here, Halidé Hanum. I have a heart as good as yours, and it keeps me awake at night to think of the human suffering. But that is a personal thing, and I am here on this earth to think of my people and of my sensibilities. If a Macedonian or Armenian leader gets the chance and excuse he never neglects it. There was an equal number of Turks and Moslems massacred during the Balkan war, yet the world kept a criminal silence. I have the conviction that as long as a nation does the best for its own interests and succeeds, the world admires it and thinks it moral. I am ready to die for what I have done, and I know that I shall die for it. ${ }^{38}$

On the orders of Adolf Hitler, Talaat's remains were exhumed in March 1943 from the Turkish Cemetery in Berlin-Neukölln and buried in a grave of honor on Liberty Hill in Istanbul in the presence of the then German ambassador Franz von Papen. Hitler hoped in vain that this would make the neutral Turkish Republic a German ally. ${ }^{39}$ To this day Talaat is revered as a patriotic martyr in his homeland and in the Turkish diaspora. Three mosques in Ankara and Istanbul bear his name. ${ }^{40}$ Seven city districts, three boulevards and 21 streets of various large cities also bear Talaat's name. ${ }^{41}$

\section{Soghomon Tehlirian, the Avenger}

Born on 2 April 1896 in the village of Nerkin (Inner) Bagarij (fuqunh6) in Erzurum Province, Tehlirian was raised in nearby Yerznka (Erzincan) since 1905, after his father was arrested and sentenced to six months imprisonment. During this time, the Tehlirian family moved to Erzincan, where Tehlirian received his initial education at the Protestant elementary school. After graduation at the Armenian Central Lyceum (Getronagan) of Constantinople, he went to study engineering in Serbia. "He was in Serbia, having moved there quite

37 Hosfeld, Operation Nemesis, 16

38 Halidé Edib Adivar, The Memoirs of Halidé Edib (Piscataway, NJ: Gorgias Press, 2005), 387.

39 Tessa Hofmann, "Der Prozeß Talaat Pascha: Vorwort zur Neuauflage," In: Der Völkermord an den Armeniern vor Gericht: Der Prozeß Talaat Pascha. Neuauflage; hrsg. u. eingeleitet von Tessa Hofmann im Auftrag der Gesellschaft für bedrohte Völker (Göttingen, Wien: Reihe pogrom, 1980); Robert Fisk, "My conversation with the son of Soghomon Tehlirian, the man who assassinated the organizer of the Armenian genocide," Independent, 20 June 2016, at https://www.independent.co.uk/voices/robert-fisk-armenian-genocide-conversation-son-soghomon-tehlirian-mehmet-talaat-pasha-assasination-a7091951.html, accessed 21.06.2016.

40 "Talaatpaşa Camii”": 1) Ankara-Dikmen, Gökkuşağı Mahallesi, 8. Sokak, No. 9; 2) İstanbul-Kağıthane, Talaatpaşa Mahallesi, Aslangazi Caddesi, No. 22; 3) İstanbul-Maltepe, Cevizli Mahallesi, Talaatpaşa Caddesi, No. 22, at http://www.aga-online.org/worship/Talaat-pasha.php?locale=de, accessed 21.06.2019. 41 See at http://www.aga-online.org/worship/Talaat-pasha.php?locale=de, accessed 21.06.2019. 
by chance on the very day in June 1914 that Gavrillo Principe shot the Archduke Ferdinand in Sarajevo, setting off the First World War." 42

During the Bolshevik Revolution of 1917, Tehlirian went to Russia and joined General Antranig Ozanian's Armenian volunteer force, fighting alongside the regular Imperial Russian army against the Ottomans, while those family members who had stayed in Erzincan were deported in June 1915.

After the World War, Tehlirian learned in Constantinople at a lecture by Dr. Melkon Gülistanian that the original list of the Armenian elite arrested in the Ottoman capital on 24 April 1919, had been compiled by a Harutyun Mkrtchyan for Bedri Bey, the president of the capital's police force. Gülistanian was one of the few survivors of those arrested at the time. ${ }^{43}$ In March 1919, Tehlirian shot Mkrtchyan in Constantinople. This first assassination drew the attention of the Nemesis network to Tehlirian, who was invited to Boston and put on Talaat as the "number one" on Shahan Natali's hit list.

Nevertheless, as Tehlirian's biographer Edward Alexander points out, Tehlirian was neither a murderer nor a mere tool of the secret organization Nemesis. He was also not a terrorist, because he was not driven by any nationalist or other ideology. He was driven by an obsession to take revenge on the man he considered to be mainly responsible for the destruction of his family:

Once that was done, the torment in his soul subsided and Tehlirian never killed again. The ARF's motive in having Talaat killed was political. Tehlirian's motive was vengeance. He was not a soldier in an ideological cause, nor fighting for territorial integrity, nor was he the agent of a political faction. Although a loyal member of the ARF, under whose auspices he carried out the assassination, he was a member in name only, executing the deed for his own sake rather than for any political program. ${ }^{44}$

Marian Mesrobian MacCurdy rightly points out that revenge was the motive for all those involved in the planning of the attack on Talaat, as they all lamented the loss of relatives " and therefore felt compelled, once it was clear that the Allies would not hold the Turks accountable, to mete out justice themselves. " 45

After his deportation from Germany in 1921, Tehlirian returned to Serbia, where he lived with his wife in Belgrade until 1950. From there the couple moved to Casablanca. "Having been told by the ARF that Turkish agents were closing on him in 1956 he moved to the United States. " 46

In San Francisco Tehlirian worked as a postal employee under the alias Saro Melikian. His younger son characterized him as follows:

He was the most gentle, mild man you could ever meet, almost naïve. Me and my

42 Fisk, "My conversation with the son of Soghomon Tehlirian."

43 Edward Alexander, A Crime of Vengeance: An Armenian Struggle for Justice (NY etc: The Free Press / Collier Macmillan, 1991), 43.

44 Ibid., 200.

45 Mesrobian MacCurdy, Sacred Justice, 123.

46 Shiragian, Gomideh. 
older brother had to force him to tell us what happened. He never liked to talk about it. He was a man of very few words. He used to write poetry and draw very well. ${ }^{47}$

\section{The Court Case against Tehlirian}

In 1985, when I was able to view the preliminary investigation file of the criminal case and other documents in the archives of the German Democratic Republic at that time, the "depoliticization" of the proceedings by the German Foreign Office and the Prussian Ministry of Justice became clear to me. ${ }^{48}$ Among other things, the German authorities feared that the criminal trial against Tehlirian might be used to discuss German-Turkish relations during WWI and especially German complicity in the extermination of the Armenians. Therefore, the trial should be conducted as swiftly as possible. Instead of the three trial days requested by the defense, the trial was conducted in only one and a half days and only nine of the 15 witnesses requested by the defense were heard.

The preliminary investigation had already ended on 21 March 1921, just seven days after Talaat's assassination. The court case itself began on 18 April 1921; on 29 March, the district attorney's office brought the charges before a jury. Even though the district attorney's office expected Tehlirian to be charged, it had him sent for a medical examination. Dr. Stoermer, the medical officer, in his diagnosis of 11 April 1921, stated that Tehlirian was "malnourished" and "inconspicuous," with scars on his skull, upper left arm, and knee, dating presumably back to the massacres. The doctor noted Tehlirian's precise description of his own medical state as follows:

Tehlirian undoubtedly suffers from epilepsy, but only in its nerve-related form, and not as a psychological disturbance... The diagnosis results from Tehlirian's own vivid descriptions. I was amazed at Tehlirian's ability to describe his illness in precise medical terms. ${ }^{49}$

The prosecution's prime question referred to whether the nervous condition he suffered would call for the application of section 51 of the Imperial Criminal Code, which would qualify Tehlirian for a plea of insanity. ${ }^{50}$

Talaat's assination caused German judicial circles considerable embarrassment. On 25 May 1921, Gollnick, the Chief Public Prosecutor, addressed the Prussian Ministry of Justice in order to explain his reservations about the legal strategy:

It is to be feared that the (forthcoming) trial by jury (...) will escalate into a mammoth political case. (...) First of all, we are sure to expect that the defense will argue on behalf of the accused that his was an act of heroism freeing Christian Armenians suffering under the Turkish yoke. (...) Perhaps the defense will even

47 Fisk, "My conversation with the son of Soghomon Tehlirian."

48 Tessa Hofmann, "New Aspects of the Talaat Pasha Court Case: Unknown Archival Documents on the Background and Procedure of an Unintended Political Trial," Armenian Review 42, no. 4/168, (1989): 41-53.

49 Record Rep. 30 Bln C, Tit. 198 B, Nr. 1182, p. 182 in the State Archives in Potsdam; Hofmann, "New Aspects of the Talaat Pasha Court Case," 43.

50 Ibid. 
try to investigate the stance of the German government on the Armenian atrocities. (...) Comparing the Polish insurrection with the Turkish (action), especially (at this time), and in England, where (politics) lends a friendly ear to the Armenians, would be (most) undesirable, as long as the Upper Silesian problem (remains unsolved).

Of even greater concern from the political point of view is a line of inquiry during the trial, which would consider (Talaat) Pasha's general political role and his German connections. Talaat was known to be the most reckless of all (representatives) with pro-German inclinations in Turkey, (and) actually not only in (Turkish) regions, but also beyond (Turkish) borders in all parts of the Islamic world. The (eyes) of the entire Islamic world will be focused on (this) trial. Public discussions about the trial would have multiple and significant political repercussions in Asia, (especially) on political relations between (Germany) and Ankara's newly-formed government. $(\ldots)^{51}$

However, Gollnick did not prevail against the Foreign Office with his proposal to conduct the proceedings in camera. From the files, we deduce that personal contacts existed between the Chief Public Prosecutor's office and the German Foreign Office, both before and after the trial.

On 1 June 1921, a day prior to the trial, in a meeting with Baron von Thermann and Count Friedrich Wilhelm von Schulenburg as representatives of the German Foreign Office, the Foreign Office representatives, clearly deviating from earlier requests, announced that a request for public exclusion by the prosecutors would be less than desirable as it could not only fail but could make a bad impression on the public. The advocates of a flexible attitude which was intended to impress the Allied powers seemed to have convinced the conservative hardliners. ${ }^{52}$

Tehlirian was represented by three lawyers: the privy judicial authority, Dr. Adolf von Gordon (Berlin; 1850-1925), whom Natali described as "conservative, but very influential. "53 Gordon's partner, Justice Counsel Dr. Johannes Werthauer (1866-1938), was one of the most prominent lawyers of the Weimar Republic, whose citizenship was revoked by the National Socialists in August 1933 on their first list. ${ }^{54}$ Tehlirian's third criminal defense attorney was the Privy Counselor Dr. Theodor Hugo Edwin Niemeyer (1857-1939), "a man of European reputation, co-founder of the International Law Association and member of the Institut de Droit Internationale, which was awarded the Nobel Peace Prize in 1904. In 1915 he founded the Journal of International Law. In 1917, on Niemeyer's initiative, the German Society for International Law was founded, which was forced to dissolve in 1933." 55

51 Ibid., 44.

52 Ibid., 45.

53 Rolf Hosfeld, Gurgen Petrossian, "Der Prozess gegen Soghomon Tehlirjan, Deutschland 1919-1921," in: Groenewold/ Ignor / Koch (Hrsg.), Lexikon der Politischen Strafprozesse, at httpss://www.lexikon-der-politischen-strafprozesse.de/glossar/tehlirjan-soghomon/, accessed 15.09.2020.

54 Ibid.

55 Ibid. 
The defense requested "at least three days adjournment." 56 The second and third days were planned for gathering evidence on the "massacres in Armenia." The defense wanted to subpoena fifteen experts and witnesses, five of whom were missionaries or had served in the German medical services in the Ottoman Empire and were eyewitnesses; two were former German consuls (Dr. Erwin von Scheubner-Richter from Erzurum, and Walter Rössler from Aleppo), and one was a member of the German imperial military mission (Lt. Col. Ernst Paraquin). Only nine of the fifteen expert witnesses were subpoenaed; five of these were medical experts on the question of Tehlirian's mental responsibility. Instead of E. Paraquin, the former Field Marshall Otto Liman von Sanders was summoned prior to the trial at the prosecutor's request. This was clearly to counteract the comprehensive testimony by Dr. Johannes Lepsius, who was generally considered an Armenophile. There was no evidence heard on Talaat's blame as author of the genocide. When von Gordon wanted to file a petition, Gollnick supplied the following counterclaim:

I request that this petition be denied. A detailed discussion on whether Talaat was responsible for the Armenian atrocities has already been permitted. The question is entirely irrelevant. In my opinion, there is no doubt that the accused was convinced that Talaat was indeed that person who could be held responsible for the atrocities. Thereby, the motive becomes very obvious. I am of the opinion that it is not the duty of this court to question Talaat's guilt. For the judgment would be a historical one, requiring evidence of a very different nature from what is present here. ${ }^{57}$

Nevertheless, thanks to the intervention of the presiding judge and District Court director Dr. Lehmberg, the prehistory of Tehlirian's deed was discussed in detail during the trial, when the defendant reported on the massacre of his family and his own survival:

This was unusual, but Lehmberg - who was very familiar with Lepsius' collection of documents on Germany and Armenia - apparently wanted to strike a major chord that gave Tehliria's "I was not a murderer" a certain credibility right from the start. The core of Tehlirian's statements about the annihilation of his family was known to Lehmberg, who repeatedly asked for details, through Lepsius' collection of documents, ${ }^{58}$ which contained comparable descriptions of the course of the massacres. ${ }^{59}$

The statements of the two Armenian witnesses and genocide survivors Christine Terzibashian (born Eftian, ca. 1894-1969) and Rev. Grigoris Palagian (Balakian; 1873-1934) supported Tehlirian's statements. Terzibashian and her family were deported from Erzurum in July 1915 and were among the remaining survivors. The cleric Palagian was one of the few Armenians who survived, having been arrested in Constantinople on 24 April 1915, and then deported to Çankırı or Ayaş. After his training in Erzurum, Rev. Palagian had pre-

56 Hofmann, "New Aspects of the Talaat Pasha Court Case," 46.

57 Ibid., 47.

58 Deutschland und Armenien 1914-1918: Sammlung diplomatischer Aktenstücke; hrsg. u. eingeleitet von Dr. Johannes Lepsius. Potsdam 1919 (Neuauflage Bremen: Donat Verlag, 1986, mit einem Vorw. zur Neuausgabe von Tessa Hofmann und einem Nachw. Von M. Rainer Lepsius), LXXX, 549.

59 Hosfeld and Petrossian, "Der Prozess gegen Soghomon Tehlirjan." 
viously studied architecture in Germany and had written a paper on the monuments of Ani, the former capital of the Armenian kingdom of Shirak. He then became a member of the clerical council in Constantinople and its secretary and proved to be an important "leader and organizer" in times of persecution of the Armenians. In March 1915, he was put on the denunciation list of Harutyun Mkrtchyan, sentenced to death but escaped execution. Rev. Palagian was 42 years old and prelate in Manchester at the time of the criminal trial against Soghomon Tehlirian. He has described his experiences not only as a witness during the trial, but also in his two-volume memoir The Armenian Golgotha. ${ }^{60}$

On 3 June 1921, after one and a half hours of deliberation, the twelve members of the jury acquitted Tehlirian. The spokesman did not give any contextual reason for the decision. In a letter to the Ministry of Justice, dated 5 June 1921, Gollnick surmised the following:

Since two medical expert witnesses confirmed the prerequisites of section 51 of the Imperial Criminal Code, we assume that the verdict of not guilty is determined based on this stipulation. The warrant was withdrawn, and Tehlirian was set free. I have sent a request to the police headquarters to have Tehlirian deported as soon as possible on the grounds of being a troublesome foreigner. ${ }^{61}$

By removing Tehlirian, the German authorities rid themselves of the cause of any further investigations. The acquittal of Tehlirian came as a surprise. In the eyes of many, especially Armenians, justice and truth triumphed. In particular, the expectations of the media-experienced Vrej organizer Shahan Natali, who, according to his own account in the newspaper Nairi (Beirut), had instructed Tehlirian as follows, were fulfilled:

You blow up the skull of the Number One nation-murderer and you don't try to flee. You stand there, your foot on the corpse and surrender to the police, who will come and handcuff you." Shahan Natalie's purpose was to turn Soghomon Tehlirian's trial into the political trial of those responsible for the great tragedy, which was realized in part. However, there were those in the ARF leadership, Simon Vratsian in particular, who had two chapters, which dealt with Shahan Natalie's leadership role in the assassination of Talaat, deleted from Tehlirian's memoirs before their printing. ${ }^{62}$

Not only the German ministries of justice and foreign affairs, but also the Vrej organizers influenced the Berlin criminal proceedings against Tehlirian, presumably through Vahan Zakariants (Zakariantz; also Zakarian) and Libarit Nazariants (Liparit Nasariantz), both members of the ARF and close collaborators of Johannes Lepsius. Nazariants was also a founding member of the German-Armenian Society (Deutsch-Armenische Gesellschaft) founded by Lepsius in June 1914. In the spring of 1915, Zakariants "with the support of the

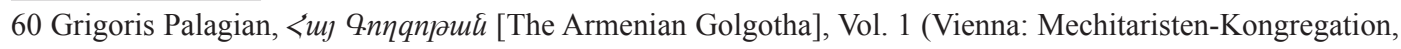
1922); Vol. 2 (Paris: Imprimerie Araxes, 1959). French edition: Le Golgotha Arménien (La Ferté-Sous-Jouarre: Le cercle d'écrits Caucasiens, Vol. 1, 2002; Vol. 2, 2004 (Band 2); American Edition: Armenian Golgotha: A Memoir of The Armenian Genocide, 1915-1918, trans. by Peter Balakian and Aris Sevag (New York: Alfred A. Knopf, 2009).

61 Hosfeld and Petrossian, "Der Prozess gegen Soghomon Tehlirjan."

62 Natalie, A Biography. 
[German] Foreign Office and under a false name, had investigated the incipient massacres in Turkey and served [1921] as Vice Consul of the Republic of Armenia in Berlin. "63

The ARF is said to have risen between 100,000 and 300,000 marks for the defense of Tehlirian. Rolf Hosfeld and Gurgen Petrossian in their recently published encyclopedia article describe Johannes Lepsius as the "actual backstage promoter of Tehlirian's defence." 64 But it remains an open and unresearched question to what extent Lepsius himself became aware of this role. Just as open remains in view of his humanitarian oeuvre as a whole the question of the general influence of the ARF on Lepsius.

In Tehlirian's criminal case, neither the existence of the secret organization Vrej, nor Tehlirian's affiliation to it, nor his membership of General A. Ozanian's voluntary units were mentioned. In his memoirs, published in 1956, Tehlirian mentioned the loss of 85 members of his extended family during the genocide, ${ }^{65}$ but in contradiction to his testimony in the Berlin criminal proceedings, he was not an eyewitness to the deportation and murder of his relatives. Tehlirian's younger son remembered in 2016: "My father never had a sister (...). He and two of his brothers were in Serbia [at the time of the genocide; T.H.]. It was his mother - my grandmother - who was killed in the genocide, along with his oldest brother Vazken, who would have been my uncle and who had been a medical student in Beirut. "66

The autobiographical narrative that Tehlirian offered when questioned by Judge Lehmberg in Berlin was thus a construct, but one that contains extremely typical and essential elements of the collective fate of his compatriots.

\section{Legal and Historical Significance}

Not only Armenian trial observers, but also the liberal and social democratic press of Germany celebrated the acquittal by the Berlin jury as a triumph of higher justice. The Jewish legal expert Robert Max Wassili Kempner (1899-1993), who had attended the trial as a young assessor, wrote in retrospect on the occasion of the 60th anniversary of the criminal trial:

The general deportation of the Armenians was decided by the Young Turk Committee during the First World War, ordered by the Minister of Interior Talaat Pasha and carried out with the help of the Young Turk Committee until the Armenians were massacred. More than two thirds of the Armenian people became victims of this holocaust. As a student at the law faculty of the Friedrich-Wilhelm-University in Berlin, I became aware of the terrible human, political and legal tragedy of this genocide, when three years after the end of the war, the Armenian student Solomon Teilirian shot the former Turkish Minister of the Interior Talaat Pasha, who also lived there, in Berlin. The ensuing murder trial before the jury court of the Berlin district court III, which took place on June 2 and 3, 1921, under the chairmanship of district court director Dr. Lehmberg, shook up the whole world. There were still

63 Hosfeld and Petrossian, "Der Prozess gegen Soghomon Tehlirjan."

64 Ibid.

65 Soghomon Tehlirian, Yhyjhznu\{itin [Recollections] (Cairo: Husaper, 1953), 8.

66 Fisk, "My conversation with the son of Soghomon Tehlirian." 
jurors in Berlin: Teilirian was acquitted, the twelve jurors coming to the conclusion in a one-hour secret deliberation that the deed was an act of passion by a mentally unstable young man who was under the terrible trauma of the Armenian extermination. ${ }^{67}$

In summary, Kempner concluded: "It was a fair and just trial. Its objective conduct was particularly commendable because Turkey was allied with the central powers during the First World War." ${ }^{68}$

In the Nuremberg war crimes trials in 1945/6, Kempner appeared as the main US prosecutor Robert Jackson's deputy. In 1947 Kempner detected the so-called Wannsee Protocol.

The criminal trial of 1921 also left a deep impression on the Polish Jewish jurist Raphael Lemkin (1990-1959), who was born in what is now Belarus, even though Lemkin, as a student in Lemberg (Lvóv, Lviv, Lvov) only learned of its course from the press. Lemkin wrote about this key experience in his autobiography:

The court in Berlin acquitted Tehlirian. It decided that he had acted under "psychological compulsion." Tehlirian, who upheld the moral order of mankind, was classified as insane, incapable of discerning the moral nature of his act. He had acted as the self-appointed legal officer for the conscience of mankind. But can a man appoint himself to mete out justice? Will not passion sway away such a form of justice and make a travesty of it? At that moment my worries about the murder of the innocent became more meaningful for me. I did not know all the answers, but I felt that a law against this type of racial or religious murder must be adopted by the world. ${ }^{69}$

In the dilemma between impunity and lynch law, Lemkin's lasting and outstanding achievement was to have recognized the legislative gap that prevented state and major crimes such as that committed against Armenians and other Christians in the Ottoman Empire from being punished or even prevented. He heard from his Heidelberg law professor that there was no law to prevent crimes committed by a state against its citizens. Lemkin pointed out the legal inconsistencies: "It is a crime for Tehlirian to kill a man, but it is not a crime for his oppressor to kill more than a million men? This is most inconsistent. "70

On 25 May 1926, the Jewish tailor, poet and anarchist Shalom Schwarzbart (also Schwarzbard; 1886-1938), shot the Ukrainian military commander (chief ataman) Symon Petlyura dead in Paris. As the chairman of the board of directors of the Ukrainian National Republic Petliura was responsible for the massacre of Jews in 1918, in which Schwarzbart's parents had perished. Petliura's executioner Schwarzbart was declared insane after a criminal trial in 1927, just like Tehlirian six years before him. Lemkin felt confirmed by

67 Robert M. W. Kempner, "Vor sechzig Jahren vor einem deutschen Schwurgericht: Der Völkermord an den Armeniern," Recht und Politik 3 (1980): 167.

68 Ibid.

69 Donna-Lee Frieze (ed.), Totally Unofficial: The Autobiography of Raphael Lemkin (London: Yale University Press, 2013), 20.

70 Samantha Power, "A Problem from Hell": America and the Age of Genocide (New York, NY: Perennial, 2002), 17; Totally Unofficial, 20. 
the Berlin and Paris jury's decisions: "The perpetrator is insane and therefore must go free. [...] Gradually, the decision was maturing in me that I had to act." "71

Lemkin's life's work became the drafting and implementation of an international treaty on the prevention and punishment of genocide. The first attempts to introduce such a convention into the League of Nations failed in $1933^{72}$, and it was only after another world war and genocide on an even larger scale that the United Nations adopted the Convention on the Prevention and Punishment of the Crime of Genocide in 1948, the essential parts of which were prepared by Lemkin. The definition of genocide contained therein is empirically based on the historical examples of the extermination of the Armenians in 1915/16, the so-called Simele massacre of Arameans and Assyrians in Iraq in 1933, and the extermination of European Jewry (Shoah) in WWII. As early as 1943, Lemkin had introduced the term genocide, which has been in international use ever since, into historical and legal literature. Until then, French publicists and British politicians such as Winston Churchill ${ }^{73}$ or Lloyd George called

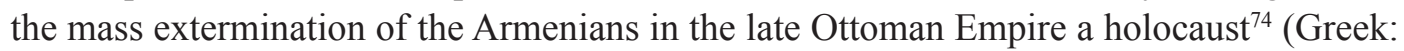
"whole-burn sacrifice").

\section{Media, Scientific and Cultural Processing}

The fact that the German judiciary had to face the crimes of Germany's previous ally Ottoman Turkey on account of the case against Tehlirian, brought the proceeding from the very beginning into the center of public attention, ${ }^{75}$ even though the prosecution had been trying to take the political element out of the trial. Despite such efforts, the trial received international media attention from the following newspapers and news agencies: The New York Times, The Chicago Daily News, Philadelphia Public Ledger, The Daily Telegraph (London) and the Agency for International Coverage, NZ: Nachrichten-und Artikel-Zentrale für Zeitungen. ${ }^{76}$

\section{Ibid.}

72 Heinsohn, Lexikon der Völkermorde, 236.

73 Winston Churchill, The World Crisis, Vol. 5, A Aftermath 1918-1928 (New York: C. Scribner's sons, 1929), 157.

74 The frequent use of fire in the destruction of the Ottoman Christians is noteworthy. The term "holocaust" as a synonym for genocidal destruction was applied by the American missionary Corinna Shattuck, who witnessed the "great holocaust" in Urfa, when three-thousand Armenians were burnt alive in their cathedral in late 1895. The term was then continuously used by Europeans to describe the annihilation of Ottoman Christians. In 1898 the French-Jewish journalist Bernard Lazare called the nationwide slaughter of Armenians and other Christians during 1895 and 1896 a holocaust, while the Englishman Frederick Zacheus Duckett Ferriman (1856-1934) titled his book on the Adana slaughter The Young Turks and the Truth About the Holocaust at Adana in Asia Minor During April 1909 (London, 1913). With the disappearance of the Christian population in Asia Minor, the historic context of "holocaust" as a synonym for anti-Christian destructive events sank into oblivion. During and after WWII, it was increasingly applied to the destruction of the European Jews, although Elie Wiesel believed, that he had invented it in 1958. Cf. Heinsohn, Lexikon der Völkermorde, 17.

75 Stefan Ihrig, "Genocide Denied, Accepted, and Justified: The Assassination of Talât Pasha and the Subsequent Trial as a Media Event in the Early Weimar Republic," Journal of the Society for Armenian Studies 22 (2013):153-177.

76 An online press review created by Heinz Böke contains German and foreign press reports on the assassination, burial and transfer of Talaat's mortal remains to Istanbul in December 1942, the state funeral on February 25, 1943 and the criminal proceedings against Soghomon Tehlirian in 1921: at https://3759d405a-62cb3a1a-s-sites.googlegroups.com/site/nichtichbindermoerder/literatur-tip-1/pressespiegel1921/Pressespiegel_1921_Der_Mord_an_Talaat_Pascha.pdf?attachauth=ANoY7co-bxRLkEtoztkh6Am2ObX6TBO8076b- 
The court case caused a feud between German social-democratic and bourgeois (nationalistic) newspapers, especially between Vorwärts and Deutsche Allgemeine Zeitung (DAZ). Adopting Turkish criticism of the verdict, the $D A Z$ called it a "judicial scandal." $D A Z$, which was a kind of semi-official government gazette during the First World War and was under the leadership of the former naval attaché in Constantinople, Hans Humann, "ignited a real anti-Armenian campaign after the assassination. A blinded cowardly assassin is Tehlirian, a 'murder jack' who shot an old man in the back. "77

However, in spite of all the controversial viewpoints, all German papers focused their critics on the conspicuously apolitical nature of the trial:

The judge and the prosecutor ardently tried to treat the case as a non-political case. Their efforts were unilaterally focused upon the inner aspects of the crime. The fear of the murder gaining political attention rendered them relatively powerless in the face of the accordingly one-sided defense which capitalized successfully both on itself and the assassin. ${ }^{78}$

Comparing this trial with the German war criminal trials in Leipzig (1921-1927), the social-democratic press called it the "first real war criminal case," even though questions on Talaat's personal responsibility for the extermination of the Armenians, or that of German involvement ${ }^{79}$ had not been sufficiently answered. ${ }^{80}$

Five years later, after the assassination of Symon Petliura, the National Socialist ideologist Alfred Rosenberg drew a parallel with the assassination of Talaat in the magazine Der Weltkampf, which he directed. Rosenberg praised Talaat for his pro-German attitude and, like other commentators before him, lamented the alleged role model effect of the acquittal of the avenger:

NGIdc01WMg3xQWV2DsvlAdjXKhVOzBCVypbdGk7XKEPia26KvCs0VEhkixDNYJ9t4WMCZUrEBBC5q2NLsIl6vvNF90BHBwOk-Pu641uyBPaB6B52MRhwjBDtMcrgtvylnwUh_ulPg57n_7JYrWrNmjgs0RqNb2hHx_QzpjRitpeK6U7fkWjhhWnbvGsUH-LCFG8oDbfQZ1wwkAHZWXb1xU3qagxhM7R4vFs4XRDiBcoQSTS9FE_PfU7rwqLU1H6bpXWWdYrinwIUUyfan3CGgw2v--EucFjA0yNgWzLm\&attredirects=0.

77 Hosfeld, Operation Nemesis, 13.

78 Deutsche Allgemeine Zeitung (Berlin) 9 Juli 1921.

79 To date, the question of collective or individual German culpability has not been dealt with comprehensively in scientific terms. Ottoman contemporaries, Christians as well as Muslims, were largely convinced that the German state was to blame for the genocide against the Armenians. But Vahakn N. Dadrian's theses in this regard have been rejected by critics as extreme. Two investigative German journalists, Wolfgang Gust and Jürgen Gottschlich, failed to provide sufficient evidence of a general German state responsibility. I myself assume that the responsibility of the German Empire consisted in the knowledge and largely tacit, tolerating acceptance of the state crimes committed during WWI by the allied Young Turk regime against the Christian and especially the Armenian population in the Ottoman Empire and in the Ottoman-occupied territories of northwestern Iran. Cf. Vahagn Dadrian, German Responsibility in the Armenian Genocide: A Review of the Historical Evidence of German Complicity (Watertown, MA: Blue Crane Books, 1996); Jürgen Gottschlich, Beihilfe zum Völkermord. Deutschlands Rolle bei der Vernichtung der Armenier (Berlin: Links, 2015); Tessa Hofmann, "Le génocide arménien vu d'Allemagne: La mise en place d'une tradition d'indifférenceLa mise en place d'une tradition d'indifférence," Politique Internationale - La Revue, Supplément au no 147 (2015), at

https://archives.politiqueinternationale.com/revue/read2.php?id_revue=147\&id=1397\&content=texte (English version at

https://www.academia.edu/13681412/Le_g\%C3\%A9nocide_Arm\%C3\%A9nien_vu_dAllemagne_La_mise_ en_place_dun_tradition_dindiff\%C3\%A9rence); Stefan Ihrig, Justifying Genocide: Germany and the Armenians from Bismarck to Hitler (Cambridge, MA: Harvard University Press, 2016).

80 Vorwärts (Berlin) 4 July 1921. 
Even during the First World War the Armenians led the espionage against the Turks, similar to the Jews against Germany. This forced the loyal ally of the German Reich, Talaat Pasha, to sharply intervene, although some hardships could not be avoided. (...) After the collapse of 1918, Talaat now lived in the capital of the country to which he had remained loyal and was murdered here. The major press of this country, however, insulted him even after his death, ${ }^{81}$ stood protectively before his murderer and demanded his acquittal. And indeed, the Berlin court acquitted the Armenian Teilerian [sic!]. The Jewish press of all shades rejoiced and called the acquittal the "only possible" verdict." 82

As early as 1921, the German writer Armin T. Wegner published the stenographic protocol of the proceedings of the Berlin trial with appendices, which included some of Talaat's telegraphic orders provided by the journalist Aram Antonian (Andonian; 1875-1951). ${ }^{83}$

But the medial and public attention was short-lived. ${ }^{84}$ Even before the Nazis came to power in 1933, the coverage of the Armenian genocide and related issues had disappeared from German media and subsequently fell into a long-lasting oblivion. Only in the late 1970s and early 1980s was the Ottoman genocide against the Armenians reintroduced through a series of publications. Among the "early" post-WWII book publications were the new editions ${ }^{85}$ of the stenographic protocol by the German human and minority rights NGO Geellschaft für bedrohte Völker (Society for Threatened Peoples), whose publications brought the issue of the international recognition of this case of genocide to the forefront in post-war German society. In 2003, the courageous Istanbul based Belge publishing house had this edition published into Turkish, after the Turkey born writer Doğan Akhanlı translated the proceedings into Turkish ${ }^{86}$; in the same year, a second volume followed with comments and articles, again translated by D. Akhanl1. ${ }^{87}$

The numerous attacks on Turkish and non-Turkish institutions and diplomats by the $\mathrm{Ar}$ menian Secret Army for the Liberation of Armenia (ASALA), which was active primarily in

81 This assertion is exaggerated. In the upper middle-class daily Deutsche Allgemeine Zeitung, for example, Lieutenant General (ret.) Bronsart von Schellendorf took the floor for Talaat, justifying the deadly forced resettlement of the Armenians or trivializing its consequences: "Talaat has become a victim of his love for his country!" Bronsart v. Schellenberg was chief of the general staff of the Ottoman field army. Cf. the above "Ein Zeugnis für Talaat Pascha," Deutsche Allgemeine Zeitung (Berlin) no. 342, Beiblatt Morgenausgabe, 24. Juli 1921. 82 Alfred Rosenberg, "Mörder und Mörderschutz," Der Weltkampf, Juli 1926, reprinted in Alfred Rosenberg, Kampf um die Macht: Aufsätze von 1921-1932 (München: Zentralverlag der NSDAP, 1938), 435-436.

83 Der Völkermord an den Armeniern vor Gericht: Der Prozess Talaat Pascha. 2. Aufl. d. Ausg. Berlin 1921, hrsg. u. eingel. von Tessa Hofmann (Göttingen, Wien: Gesellschaft für bedrohte Völker, 1980), XI, 136. A selection of Talaat's orders in German translation was published on pages 133-136; The Memoirs of Naim Bey: Turkish Official Documents Relating to the Deportation and the Massacres of Armenians, compiled by Aram Andonian (London: Hodder \& Stoughton, 1920).

84 Tessa Hofmann, "From Silence to Re-Remembrance: The Response of German Media to Massacres and Genocide against the Ottoman Armenians," in Mass Media and the Genocide of the Armenians: One Hundred Years of Uncertain Representation, ed. by S. Kappler, S. Kasparian, R. Godin, J. Chabot (Basingstoke, Hampshire: Palgrave Macmillan, 2016), 94-96.

85 Under the title "Der Völkermord an den Armeniern vor Gericht" (1980, 1985).

86 Talaat Paşa Davası - I (2 - 3 Haziran 1921), çev. ve yay. haz. Doğan Akhanlı (Istanbul: Belge Yayınları, 2003).

87 Talaat Paşa davası-II (2 ve 3 Haziran 1921): bilinmeyen belgeler yorumla, çev. ve yay. haz. Tessa Hofmann ve Doğan Akhanlı (Istanbul: Belge Yayınları. Aralık 2003). 
the 1970s-1980s, and by three other lesser-known Armenian "Justice" commands drew the attention of the public media and journalists to Operation Nemesis as the supposed origin of Armenian terrorism. The $95^{\text {th }}$ and $100^{\text {th }}$ anniversary of the Ottoman genocide against the Armenians offered further occasions for such publications. Beginning with Les vengeurs arméniens by the French investigative journalist Jacques Derogy (d.i. Jacques Weitzman, 1925-1997), seven monographs have been published in France, the USA, and Germany to date, dealing with the assassination by Tehlirian, the Berlin criminal trial, and the clandestine Nemesis organization; four of the seven authors are of Armenian origin. ${ }^{88}$ Derogy was the first to reveal the connection between the assassination of Talaat and Vrej. However, it was not until 2019 that Armenian historians took notice of his groundbreaking monograph. ${ }^{89}$

No less stimulating were the events of 1921 in the artistic field. Even before the book publications, two documentary films and a feature film were produced since 1982. The 1982 American film Assignment Berlin, directed by the Beirut born producer Hrayr Toukhanian, chronicles Talaat's assassination. The semi-autobiographical French film Mayrig (1991) with Claudia Cardinale and Omar Sharif by Henri Verneuil depicts Talaat's assassination and Tehlirian's trial. The 2015 documentary film Execution on the Open Street by Bernard George was broadcast on the Franco-German television channel ARTE on 28 April 2015 on the occasion of the 100th anniversary of the genocide commemoration..$^{90}$

The story of Talaat's assassination and Tehlirian's acquittal, as revealed by the trial's proceedings, is one of a double paradox: the assassination victim proves to be responsible for mass murder, whereas the perpetrator belongs to the group of victims. This is what the title Murderer's Murder (Mördermord) in the historical novel $(2002,2012)$ by the German authors Günther Fuchs and Hans-Ulrich Lüdemann allude to. It was followed in 2005 by the play History Tilt by the German author and theatre director Hans-Werner Kroesinger, ${ }^{91}$ which was performed on several Berlin stages. A civil society initiative was the scenic performance Nicht ich bin der Mörder! (I am not the murderer!), in which German, Armenian and Turkish actors and actresses, together with a French pianist, read from the minutes of the trial under the direction of Heinz Böke between February 2010 and 2016, not just in Berlin. ${ }^{92}$ A resumption of the reading is planned for the 100th anniversary of the criminal trial

88 In chronological order these are the following monographs - Jacques Derogy, Les vengeurs arméniens; Edward Alexander, A Crime of Vengeance; Jonathan Bass, Stay the Hand of Vengeance: The Politics of War Crimes Tribunals (Princeton: Princeton University Press, 2001); Hosfeld, Operation Nemesis; Vartkes Yeghiayan, The Case of Soghomon Tehlirian (Glendale, CA: Center for Armenian Remembrance; 2nd edition, 2006); Eric Bogosian, Operation Nemesis: The Assassination Plot that Avenged the Armenian Genocide (New York: Little, Brown \& Company, 2015); Mesrobian, Sacred Justice.

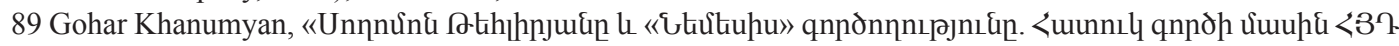

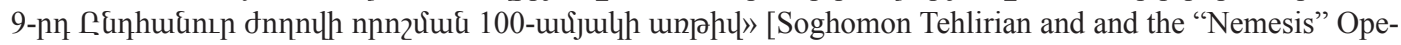
ration: To the 100th Anniversary of the 9th General Assembly Resolution of ARF Dashnaktsutyun on the Special Project], VEM Pan-Armenian Journal 68, no. 4(2019): 67-84.

90 “Ausstrahlung am 28. April um 21.45 Uhr," at https://info.arte.tv/de/hinrichtung-auf-offener-strasse, accessed 24.11.2019.

91 "DAS BÜROKRATISIERTE GRAUEN, Hans-Werner Kroesinger: History Tilt, Hebbel am Ufer (HAU3), Berlin / Maxim Gorki Theater (Studio Я), Berlin (Regie: Hans-Werner Kroesinger)," at https://stagescreen. wordpress.com/2015/03/14/das-burokratisierte-grauen/, accessed 24.11.2019.

92 “Der Prozess Talaat Pascha," at https://sites.google.com/site/nichtichbindermoerder/, accessed 12.02.2019. 
in June 2021. The district court (Landgericht) Berlin gave permission to stage the reading from the court proceedings protocol in the premises of the district court itself, presumably in the same courtroom No. 700 where the court case against Tehlirian took place a hundred years ago.

\section{Berlin-Charlottenburg as a Crime Scene and a Place of Memory and Learning}

Berlin is currently a city with an ambivalent culture of remembrance with regard to WWI and the reappraisal of the German - Ottoman - Young Turk alliance during that period. In its district of Charlottenburg, Germany's capital city has an ecumenical memorial in a semi-public space for the victims of the Ottoman genocide(s) by the Young Turks and Kemalists against about three million indigenous Christians in Ottoman territories and Ottoman-occupied northwestern Iran. At the same time, the Turkish cemetery at the Şehitlik mosque in the district of Neukölln honours the genocide perpetrators Cemal Azmi and Bahaddin Şakir shot by Vrej members in 1922 as patriotic 'martyrs'. There were also initiatives after 2005, within Berlin's Turkish community, to erect a memorial plaque on Hardenbergstrasse in memory of Talaat as a victim of "Armenian terrorism." The socialist Kurdish-born delegate to Berlin's state parliament, Giyasettin Sayan, asked the government in the Berlin Senate, in his Minor Interpellation"3 of 29 March 2005, about its knowledge of the "graves of honour" for Cemal Azmi and Bahattin Şakir at the Şehitlik (Martyrs') Mosque ending with the question:

What initiatives and measures does the senate want to take in order to counteract the historical revisionism, both regarding the German role in the genocide against the Armenians, and the role of the young Turks at that time, but also the participation of the population in the genocide against the Armenians? ${ }^{94}$

The answer of the Berlin state government of 4 April 2005, which was given even before the adoption of the first Bundestag resolution on the Ottoman Genocide (June 2005), was pleasingly clear:

The Senate is aware of the events surrounding the Armenian genocide, especially since the German Reich was also involved in the matter and Berlin was the scene of various actions in connection with that genocide. The graves at the Turkish Cemetery that have been mentioned are not graves of honour of the state of Berlin. ${ }^{95}(\ldots)$

93 In German parliamentarianism, a Minor Interpellation by a member of parliament to the government must obligatorily be answered by the government.

94 "Armeniergenozid," at http://www.aga-online.org/news/attachments/kleine_anfrage_sayan.pdf, accessed 22.03.2019.

95 This means that the Islamic (Turkish) cemetery and the Şehitlik mosque are located on extraterritorial grounds. The foundation of the cemetery at Columbiadamm in the Berlin district of Neukölln dates back to 1866, when Emperor Wilhelm I permanently ceded the area as a burial place to the Turkish community in Berlin; the inauguration took place on 29 December 1866. See at https://www.berlin.de/sehenswuerdigkeiten/3560303-3558930-islamischer-friedhof-am-columbiadamm.html, accessed 22.03.2019. However, and in contrast to the previously quoted information by the Land Berlin, the mosque association states that the area was bought from the Prussian King Friedrich Wilhelm III for 40 Taler. Among the "many important and 
The Senate supports initiatives and measures to comprehensively process even uncomfortable chapters of history and to disseminate knowledge about them. Against this background, the representative of the Senate for Integration and Migration has commissioned a publication by the expert on Armenian affairs, Dr. Tessa Hofmann, in which the history and present state of the Armenian diaspora in Berlin is presented. This brochure ${ }^{96}$ includes the genocide of the Armenians. The work also picks up on the increasing number of voices from Turkey, that are calling for an open approach to this topic, which has been taboo in Turkish historiography until now. The Senate hopes that this publication will contribute to objective and unprejudiced information and processing of these chapters of Armenian-German-Turkish history. ${ }^{97}$

However, the worship of perpetrators within the diaspora of Turkish origin, which still persists 15 years later, must continue to be countered with educational information offers. Further civil society activities are therefore planned for 2021, including lectures and city tours in Berlin-Charlottenburg.

well-known personalities" who are buried here, the mosque association explicitlycounts Cemal Azmi and Dr. Bahattin Şakir Bey as well as Talaat. The Şehitlik Mosque is under the control of the Turkish state authority for religion DITIB, at http://sehitlik-moschee.de/?p=355, accessed 22.03.2019.

96 Tessa Hofmann, Armenier in Berlin - Berlin und Armenien (Mit Beiträgen von Doğan Akhanlı und Yelda. Berlin: Der Beauftragte des Senats für Integration und Migration, 2005), 104.

97 "Armeniergenozid." 